\title{
Internal branding at university: Do tenure and job security matter?
}

\section{Marta Retamosa ${ }^{1}$, Ángel Millán ${ }^{1}$, Juan A. García ${ }^{3}$, María Millán ${ }^{4}$}

${ }^{1}$ Department of Marketing, Universidad de Castilla-La Mancha, Ciudad Real, Spain, ${ }^{3}$ Department of Marketing, Universidad de Castilla-La Mancha, Talavera de la Reina, Spain, ${ }^{4}$ Faculty of Education, Universidad de Castilla-La Mancha, Ciudad Real, Spain.

\begin{abstract}
Universities, as educational service providers, must pay attention to their employees who are pivotal in delivering and communicating brand promise and service quality to the stakeholders. While branding initiatives most frequently focus on external stakeholders, internal branding efforts establish systems/processes and consequent employees' behaviour that are consistent with external branding efforts. With a sample of 753 faculty members and researchers from a Spanish public University, the study aims to establish if employee tenure and job security have a significant relationship with employees' brand commitment and employees' brand supporting behaviour. An analysis of variance was carried out for testing the hypothesis. Differences were found according to tenure in employees' brand commitment while job security did not impact significantly on employees' brand commitment. In addition, a positive and significant relationship were found between employees' brand supporting behaviour and tenure, but not for job security. For business practitioners, this research state that it is essential for service companies, such as universities, to use differing approaches to employees according to their organisational tenure as an important managerial implication.
\end{abstract}

Keywords: Internal Branding; Job security; Employee tenure; Employeebrand supporting behaviour; brand commitment. 


\section{Introduction}

Universities now operate in an environment characterized by high competition, the lack of financing and declining demand for students (Assad et al., 2013; Yu et al., 2018). As a result, many institutions of higher education (HEIs) are gradually adopting market-oriented strategies to differentiate themselves from competing universities. In this context, the brand strategy is a fundamental tool to gain competitive position and differentiate (HemsleyBrown \& Lowrie, 2010).

Heretofore, previous studies have been more focused on the external aspects of the brand and the perspective of students (Stephenson \& Yerger, 2014), ignoring the importance of managing the brand internally. While branding initiatives most frequently focus on external stakeholders, internal marketing, employee branding and/or internal branding efforts establish systems/processes and consequent employees' behaviour that are consistent with external branding efforts (Aurand et al., 2005).

Employees who are in consensus with an organisation's brand are more likely to act consistently in ways supporting how the organisation hopes that external constituencies perceive it and its products/services (Aurand et al., 2005). While employees are pivotal in delivering and communicating brand promise and service quality to external stakeholders, the relevance for HEIs to engage their employees in the brand building process is acknowledged (Judson et al., 2009).

Nevertheless, organisations should pay attention to the differences between different demographic and psychographic groups of employees (Allen \& Meyer, 1990; Yu et al., 2018). Tsui et al. (1992) found that employees' psychological commitment and behaviours might vary because of demographic heterogeneity. Moreover, other studies have identified those variables that might influence organisational and brand identification and commitment ( $\mathrm{Yu}$ et al., 2018). These studies have evaluated personal variables (e.g. age and gender) and situational variables (e.g. tenure and function).

However, to date, there have been few analyses of the relationship between these situational variables (tenure and function) and different dimensions of internal branding like brand commitment and employee brand supporting behaviour. This study aims to examine differences in brand commitment and employee brand supportive behaviour, according to tenure and job security. 


\section{Theoretical background}

\subsection{Brand commitment}

The concept of employee commitment is central at an organisational strategy. Typically, is defined as the relative strength of an individual's identification with the involvement in a particular organisation, characterised by strong acceptance of and a belief in an organisation and a strong desire to maintain membership of the organisation (Mowday et al., 1982).

The conceptualization of brand commitment employed in this research derives from Allen and Meyer's (1990) definition of organisational commitment and is described as a psychological state that exemplifies an employee's relationship with the brand. Although Allen and Meyer (1990) acknowledge three distinct types of commitment (i.e., affective, normative, and continuance), we focus only on affective commitment, which is defined as employees' emotional attachment to the brand. Previous studies have already demonstrated the importance of the commitment in internal branding process (Xiong \& King, 2015).

According to Van Nguyen et al. (2019), employees, the longer their organisational tenure, the more familiar they will become with their role and organisational culture. Therefore, accumulating years of tenure could affect their ability to seek out and absorb the brand awareness provided by the organization's internal brand campaigns.

In this study, the organisational tenure concept refers to the number of years an individual has spent working for a respective organisation (Oshagbemi, 2000). Strong identification is developed over the long term, when individuals have passed an extended period working in an organisation and have embedded the organisation's objectives, and key attributes into their self-concepts (Hammed et al., 2013). Riketta (2005) found using a meta-analysis study that tenure is significantly related to organisational identification.

Another variable considered at this study is job security. Probst (2003) defined this concept as the perceived stability and continuance of one's job as one knows it'. It represents an employee's perceptions of whether he or she can continue to maintain employment and whether the desired characteristics of his or her job are stable.

Employees who experience job insecurity may find it difficult to predict what will happen in the future and to decide on the appropriate reaction within the organisation. In other words, they are confronted with the uncertainty of how to behave and what to expect in their work environment, and have a strong motivation to regain the social order originally expected in the organisation (Loi et al., 2014). Therefore, the following hypotheses are proposed:

\section{H1. Tenure has a positive impact on employees' brand commitment.}

H2. Job security has a positive impact on employees' brand commitment. 


\subsection{Employees' brand supporting behaviour}

Morhart et al. (2009) define employee-brand building behaviour as employees' contribution (both on and off the job) to an organisation's customer-oriented branding efforts. According to Judson et al. (2006), employee brand support can be defined as the actions of employees that deliver the brand's values to stakeholders. From a marketing and communication approach, employees tend to support their organisation's brand by means of understanding the brand an incorporating the brand values in their day-to-day operation.

Managers can enhance internal branding mechanisms by taking into consideration tenure and job security, as factors influencing in the internal branding (Dechawatanapaisal, 2019). Therefore, institutions need to plan those activities based on the organisation's brand values in order to foster brand-supportive behaviour among employees (Aurand et al., 2005).

In accordance with the literature on the theory of social identity, Picolli et al. (2017) stated that job insecurity is related to reduced levels of identification with the organisation and, consequently, to low tasks performance. By creating a sense of belonging and providing a positive basis for the social identity of employees, managers can increase involvement and attachment to the organisation. Therefore, the following hypotheses are proposed:

\section{H3. Tenure has a positive impact on employees' brand supporting behaviour.}

H4. Job security has a positive impact on employees' brand supporting behaviour.

\section{Method and results}

\subsection{Data collection and instrument}

The situation of Spanish public universities from 2012 onwards began a decline in the relative participation of permanent teaching staff, which lost 8,288 staff in the period 2008 to 2017, representing $16.2 \%$ of the total initial staff (CRUE, 2019). In this study, a sample of 753 faculty members and researchers from a Spanish public University participated in this study. An email was sent to all university staff (i.e., 2,431 according to the institutional statistics) inviting them to participate in an online survey, obtaining a response rate of $31 \%$. Most respondents were aged between 35 and 54 years $(65.6 \%)$. The tenure was ranged between 1 and 36 years, with an average of 14.93 years $(S D=8.86)$. The permanent academic staff comprised $55.2 \%$ of the sample.

In addition to the classification data (i.e., gender, age, tenure and staff position), the questionnaire also included: (1) four items to assess the employees' brand commitment, adapted from Yu et al. (2018); and (2) five items related to employees' brand supporting behaviour (Aurand et al., 2005). All items were rated on a 5-point Likert-type scale ranging from strongly disagree (1) to strongly agree (5). 


\subsection{Results}

Statistical analyses were carried out using IBM SPSS Statistics 19.0 and R version 3.6.0. Before testing the hypotheses, the reliability of the scales was evaluated using ordinal alpha $(\mathrm{O} \alpha)$, which is a measurement of the internal consistency of the items in the instrument. The $\mathrm{O} \alpha$ was 0.91 for employees' brand commitment scale and 0.84 for the employees' brand supporting behaviour scale. The scores for these two constructs were, therefore, calculated as the average of these four and five items, respectively, for the subsequent analyses.

With regard to the hypotheses testing, the differences in employees' brand commitment (H1 and $\mathrm{H} 2$ ) and brand supporting behaviour ( $\mathrm{H} 3$ and $\mathrm{H} 4)$ according to tenure and job security were studied by: (1) the one-way analysis of variance (ANOVA) procedure when the homogeneous variance assumption was correct; or (2) Welch robust test of equality of means when the variances were heterogeneous.

Regarding the employees' brand commitment (Table 1), differences were found according to tenure. Specifically, those employees who had been working at this university between 16 and 20 years had a higher brand commitment than those who had between 6 and 10 years of experience. The Spearman correlation coefficient $\left(r_{\mathrm{s}}\right)$ between brand commitment and tenure was 0.073 ( $p=0.044)$. Therefore, H1 was supported. H2 was rejected because job security did not impact significantly on employees' brand commitment.

Table 1. Differences in employees' brand commitment according to tenure and job security.

\begin{tabular}{|c|c|c|c|c|c|c|c|c|}
\hline \multirow[t]{2}{*}{$\begin{array}{l}\text { (Hypothesis) } \\
\text { Factor }\end{array}$} & \multirow[t]{2}{*}{$\mathbf{N}$} & \multirow[t]{2}{*}{$\mathbf{M}$} & \multirow[t]{2}{*}{ SD } & \multicolumn{2}{|c|}{ Levene test } & \multicolumn{2}{|c|}{$\begin{array}{c}\text { ANOVA/Welch } \\
\text { test }\end{array}$} & \multirow{2}{*}{$\begin{array}{c}\text { Games } \\
\text { Howell Test } \\
(\mathbf{p}<0.05)\end{array}$} \\
\hline & & & & $\boldsymbol{F}$ & $p$ & $F$ & $p$ & \\
\hline (H1) Tenure & & & & 2.482 & 0.030 & $2.481 \mathrm{a}$ & 0.032 & $16-20>6-10$ \\
\hline $1-5$ years & 130 & 4.38 & 0.67 & & & & & \\
\hline $6-10$ years & 144 & 4.29 & 0.72 & & & & & \\
\hline $11-15$ years & 119 & 4.33 & 0.75 & & & & & \\
\hline $16-20$ years & 166 & 4.51 & 0.56 & & & & & \\
\hline $21-25$ years & 85 & 4.43 & 0.71 & & & & & \\
\hline$>25$ years & 109 & 4.47 & 0.63 & & & & & \\
\hline (H2) Job security & & & & 0.106 & 0.744 & 1.737 & 0.188 & \\
\hline Permanent & 337 & 4.37 & 0.65 & & & & & \\
\hline Non-permanent & 416 & 4.43 & 0.69 & & & & & \\
\hline
\end{tabular}

Note: a Asymptotically F distributed. 
The results obtained in relation to $\mathrm{H} 3$ showed a positive and significant relationship between employees' brand supporting behaviour and tenure $\left(r_{s}=0.081, p=0.027\right)$. This provided support for $\mathrm{H} 3$, although the ANOVA (performed with tenure in five-year intervals) did not reveal statistically significant differences in employees' brand supporting behaviours (Table 2). H4 was, however, rejected.

Table 2. Differences in employees' brand supporting behaviour according to tenure and job security.

\begin{tabular}{|c|c|c|c|c|c|c|c|c|}
\hline \multirow[t]{2}{*}{$\begin{array}{l}\text { (Hypothesis) } \\
\text { Factor }\end{array}$} & \multirow[t]{2}{*}{$\mathbf{N}$} & \multirow[t]{2}{*}{$\mathbf{M}$} & \multirow[t]{2}{*}{ SD } & \multicolumn{2}{|c|}{ Levene test } & \multicolumn{2}{|c|}{$\begin{array}{c}\text { ANOVA/Welch } \\
\text { test }\end{array}$} & \multirow{2}{*}{$\begin{array}{c}\text { Games } \\
\text { Howell Test } \\
(\mathbf{p}<\mathbf{0 . 0 5})\end{array}$} \\
\hline & & & & $\mathbf{F}$ & $\mathbf{p}$ & $\mathbf{F}$ & $\mathbf{p}$ & \\
\hline (H3) Tenure & & & & 0.715 & 0.612 & 1.666 & 0.141 & \\
\hline $1-5$ years & 130 & 3,47 & 0,65 & & & & & \\
\hline $6-10$ years & 144 & 3,40 & 0,73 & & & & & \\
\hline $11-15$ years & 119 & 3,46 & 0,71 & & & & & \\
\hline $16-20$ years & 166 & 3,62 & 0,71 & & & & & \\
\hline 21-25 years & 85 & 3,47 & 0,82 & & & & & \\
\hline$>25$ years & 109 & 3,53 & 0,75 & & & & & \\
\hline (H4) Job security & & & & 3.516 & 0.061 & 0.672 & 0.413 & \\
\hline Permanent & 337 & 3.47 & 0.67 & & & & & \\
\hline Non-permanent & 416 & 3.52 & 0.77 & & & & & \\
\hline
\end{tabular}

Finally, two regression analyses, in which sex and age were also included as explanatory variables, were conducted to test the results' robustness. In the case of employees' brand commitment, only a significant and negative effect was obtained for the tenure interval of 6 to 10 years $(\beta=-0.238, t=-2.093, p=0.037)$. In the case of employees' brand supporting behaviour, none of the parameters associated with tenure and job security was significant.

\section{Conclusions}

The study of internal branding in universities and its effects from a marketing perspective in combination with its relevant mechanisms is crucial in order to fully understanding the way in which a brand can resonate among all its stakeholders (Sujchaphong et al., 2015).

The aim of this study is to examine the relationship between employee tenure, job security and internal brand consequences such as brand commitment and brand supportive behaviour. Findings of the study indicate that tenure has a positive influence on brand 
commitment and brand supportive behaviour. On the other hand, this research could not support the hypothesized positive effect of job security on brand commitment and brand supporting behaviour.

As an important managerial implication for business practitioners, our research state that it is essential for service companies, such as universities, to use differing approaches to employees according to their organisational tenure. That is in line with Van Nguyen et al. (2019) who stated that the effectiveness of internal branding campaigns and brand leadership might be affected by the employee tenure.

Future studies may enrich existing knowledge of employee internal branding via a crossfaculty and/or cross-discipline research. Moreover, further studies could investigate how such faculty brands co-exist and interact with the broader university brand.

\section{References}

Allen, N. J., \& Meyer, J. P. (1990). The measurement and antecedents of affective, continuance and normative commitment to the organization. Journal of Occupational and Organizational Psychology, 63(1), 1-18. doi: 10.1111/j.2044-8325.1990.tb00506.x

Assad, Y., Melewar, T. C., Cohen, G., \& Balmer, J. M. T. (2013). Universities and export market orientation: an exploratory study of UK post-92 universities. Marketing Intelligence and Planning, 31(7), 838-856. doi: 10.1108/MIP-01-2013-0007

Aurand, T. W., Gorchels, L., \& Bishop, T. R. (2005). Human resource management's role in internal branding: an opportunity for cross-functional brand message synergy. Journal of Product and Brand Management, 14(3), 163-169.

CRUE (2019). Informe La Universidad Española en cifras 2017/2018. Retrieved from: http://www.crue.org/Documentos\%20compartidos/Publicaciones/Universidad\%20Espa $\%$ C3\%B1ola\%20en\%20cifras/UEC\%201718_FINAL_DIGITAL.pdf

Dechawatanapaisal, D. (2019). Internal branding and employees' brand outcomes: do generational differences and organizational tenure matter?. Industrial and Commercial Training, 51(4), 209-227. doi: 10.1108/ICT-10-2018-0089

Hammed, I, Roques, O, \& Ali Arain, G. (2013). Nonlinear moderating effect of tenure on organizational identification (OID) and the subsequent role of OID in fostering readiness for change. Group and Organization Management, 38(1), 101-127.

Hemsley-Brown, J., \& Lowrie, A. (2010). Higher education marketing. International Journal of Public Sector Management, 23(2), 1-3. doi: 10.1108/ijpsm.2010.04223baa.002

Judson, K. M., Aurand, T. W., Gorchels, L., \& Gordon, G. L. (2009). Building a university brand from within: university administrators' perspectives of internal branding. Services Marketing Quaterly, 30(1), 54-68. doi: 10.1080/15332960802467722

Judson, K. M., Gorchels, L., \& Aurand, T. W. (2006). Building a university brand from within: a comparison of coaches' perspectives of internal branding. Journal of Marketing for Higher Education, 16(1), 97-114. doi: 10.1300/J050v16n01_05 
Loi, R., Cham, K. W., \& Lam. L. W. (2014). Leader-member exchange, organizational identification, and job satisfaction: A social identity perspective. Journal of Occupational and Organizational Psychology, 87(1), 42-61. doi: 10.1111/joop.12028

Morhart, F. M., Herzog, W., \& Tomczak, T. (2009). Brand-specific leadership: Turning employees into brand champions. Journal of Marketing, 73(5), 122-142. doi: 10.1509/jmkg.73.5.122

Mowday, R., Porter, L., \& Steers, R. (1982). Employee-Organization Commitment. The Psychology of Commitment, Absenteeism and Labour Turnover. New York, NY: Academic Press.

Oshagbemi, T. (2000). Is length of service related to the level of job satisfaction? International Journal of Social Economics, 27(3), 213-226.

Picolli, B., Callea, A., Urbini, F., Chirumbolo, A., Ingusci, E., \& De Witte, H. (2017). Job insecurity and performance: the moderating role of organizational identification. Personell Review, 46(8), 1508-1522.

Probst, T. M. (2003). Development and validation of the job security index and the job security satisfaction scale: A classical test theory and IRT approach. Journal of Occupational and Organizational Psychology, 76(4), 451-467. doi: 10.1348/096317903322591587

Riketta, M. (2005). Organizational identification: A meta-analysis. Journal of vocational behavior, 66(2), 358-384. doi: 10.1016/j.jvb.2004.05.005

Stephenson, A. L., \& Yerger, D. B. (2014). Does brand identification transform alumni into university advocates?. International Review on Public and Nonprofit Marketing, 11(3), 243-262. doi: 10.1007/s12208-014-0119-y

Sujchaphong, N., Nguyen, B., \& Melewar, T.C. (2015). Internal branding in universities and the lessons learnt from the past: the significance of employee brand support and transformational leadership. Journal of Marketing for Higher Education, 25(2), 204237.

Tsui, A. S., Egan, T. D., \& O’Reilly, C. A. (1992). Being different: relational demography and organizational attachment. Administrative Science Quaterly, 37(4), 549-579. doi: $10.2307 / 2393472$

Van Nguyen, L. T., Lu, V. N., Hill, S. R., \& Conduit, J. (2019). The mediating role of brand knowledge on employees' brand citizenship behaviour: Does organizational tenure matter?. Australasian Marketing Journal, 27(3), 169-178. doi: 10.1016/j.ausmj.2019.04.003

Xiong, L., \& King, C. (2015). Motivational drivers that fuel employees to champion the hospitality brand. International Journal of Hospitality Management, 44, 58-69. doi: 10.1016/j.ijhm.2014.10.009

Yu, Q., Asaad, Y., Yen, D. A., \& Gupta, S. (2018). IMO and internal branding outcomes: an employee perspective in UK HE. Studies in Higher Education, 43(1), 37-56. doi: 10.1080/03075079.2016.1152467 